\title{
COLUMNAROSIS IN RAINBOW TROUT (Salmo gairdneri R.) IN CZECHOSLOVAKIA
}

\author{
J. ŘKHULKA and O. MRÁZ
}

Fisheries Research Institute, Vodňany, Laboratory Ostrava, 70100 Ostrava, Department of Epizootiology and Microbiology, University of Veterinary Science, 61242 Brno

Received fune 2, 1981

\begin{abstract}
Rehulka J., O. Mráz: Columnarosis in Rainbow Trout (Salmo gairdneri R.) in Czechoslovakia. Acta vet. Brno, 51, 1982: 125-137.

The first outbreak of columnarosis in Czechoslovakia is described. The disease was observed from the beginning of May until the end of August 1980 in connection with feeding experiments performed under river and dam-lake conditions.

In river water $\left(9.8^{\circ} \mathrm{C}\right)$, oval light spots were found on various parts of the fish body. In dam-lake water $\left(16.2^{\circ} \mathrm{C}\right)$, also ulceration of the musculature or even exposure of bones of the diseased fish was observed. The course of the epizootic also differed at the two temperatures. In the first case it lasted 20 days with a loss of 390 fish (i.e. $13 \%$ ), while in the second the course was protracted throughout the entire feeding experiment and the total loss amounted 1440 fish (i.e. $24 \%$ ).

From each locality 8 fish specimens were examined. In all tissue smears gram-negative rod-shaped Flexibacter columnaris organisms were identified. Also their isolation on Anacker-Ordal agar proved successful. Further 3 times Aeromonas punctata, twice Pseudomonas aeruginosa, twice neisseriae, twice corynebacteriae and once Chromobacterium lividum were isolated as well as water moulds.

Biological experiments were performed 4 months later on rainbow trout fry using one strain of Flexibacter columnaris and one strain of Aeromonas punctata. The tests were carried out under laboratory conditions at water temperatures of $15^{\circ} \mathrm{C}$ and $20^{\circ} \mathrm{C}$.

From the inoculation scheme (Table 2) we successfully reproduced the Fl. columnaris by contact (inoculation into the water) at $20^{\circ} \mathrm{C}$, and $A$. punctata infection by i.p. inoculation into fish at both $15^{\circ} \mathrm{C}$ and $20^{\circ} \mathrm{C}$. These experiments show above all the conditioning effect of water temperature, rapid decrease in virulence of Flexibacter strains in laboratory and the secondary nature of Aeromonas punctata infections.
\end{abstract}

Epidermal necrosis, gills, ulceration, Flexibacter columnaris, Aeromonas punctata.

The causative agent of the disease was described by Davis (1922) and named Bacillus columnaris according to its typical arrangement in tissue smears. Clusters of the organisms in cultures were erroneously described as sporangia by Ordal and Rucker (1944) and the authors transferred it into the genus Chondrococcus. The real situation was only recognized by Garnjobst (1945). She gave a detailed description of the organism and a newer genus designation Cytophaga. The present name Flexibacter columnaris is based on a wider taxonomical study published by Leadbetter (1974). The merit of this author was the definitive classification of the organism in the system of bacteria whereas the species characteristics by Garnjobst has not been outdone yet.

More recently, the knowledge about columnarosis was reviewed by Wolke (1975). The condition was defined as epidermal necrosis of salmonid and aquarium fishes with subsequent ulceration with possible damage and destruction of the gills. The gross findings consist of oval lighter spots on different parts of the body surface. Their localization can change from one host species to another so that in scaly fishes more often fins and gills are invaded. A typical sign is a saddle-shaped necrosis with loss of skin substance between the dorsal and tail fins. According to the original description by Davis, the dark blue centres of lesions are surrounded by a white veil and de- 

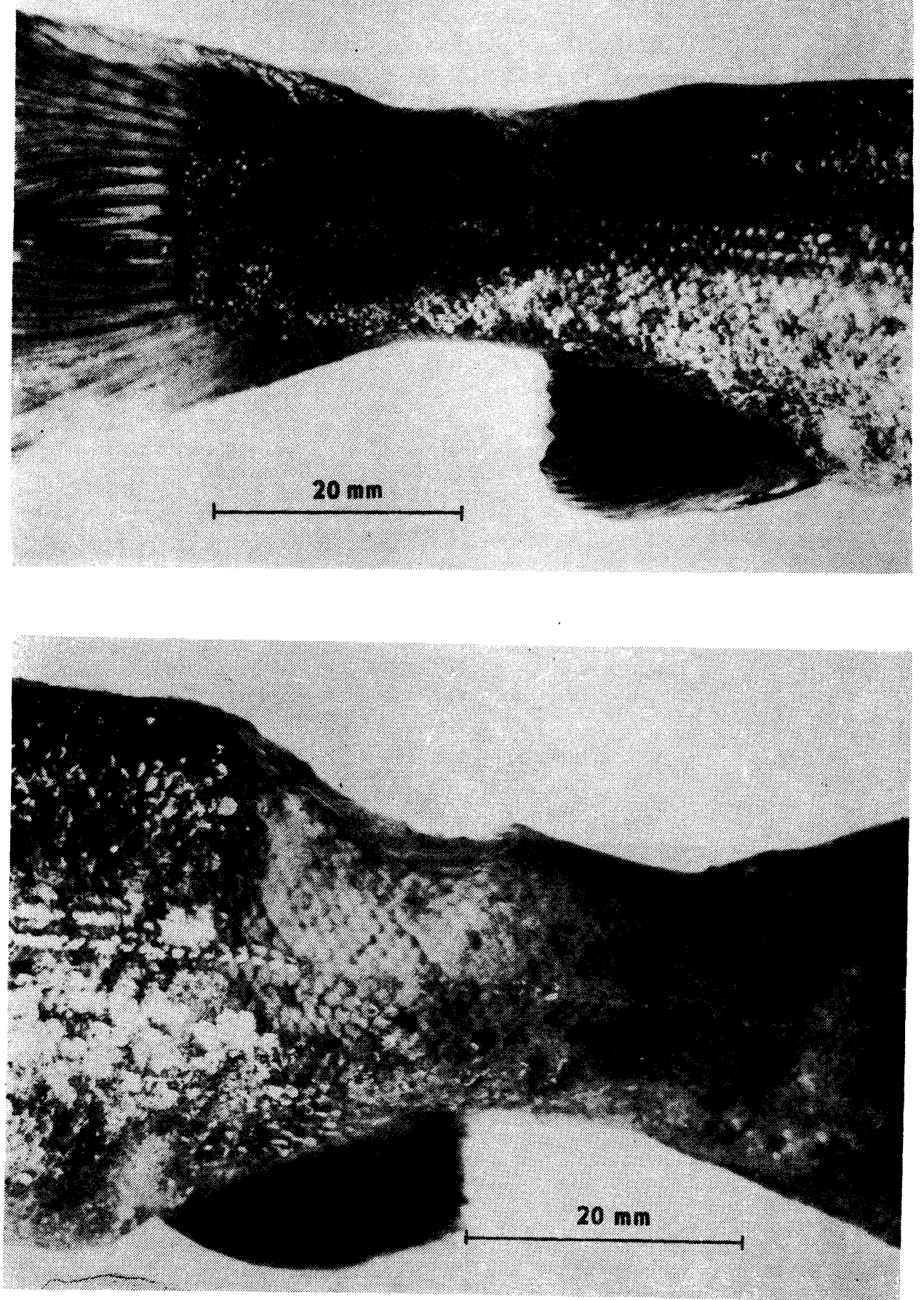

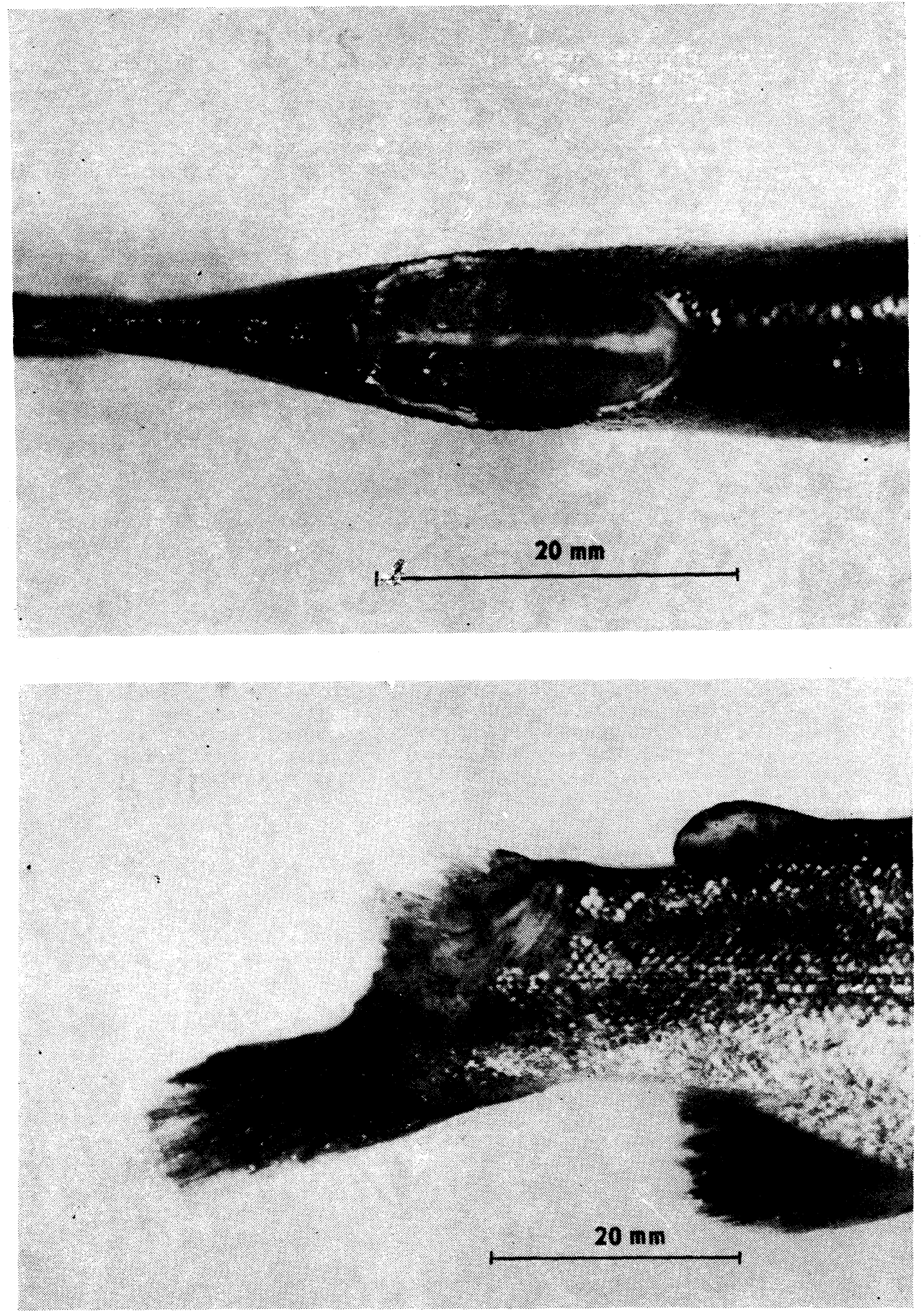

Fig. 1-4.

Columnarosis in rainbow trout: development of necrotic lesions on the tail. Natural infection. 
marcated by a thin hyperemic zone. On invaded gills, light areas with subsequent destruction of the gill filaments resulting in exposure of the gill arches (Waka bay a shi et al. 1970) appear. In peracute course of the disease all these symptoms may be absent and the fish die showing signs of suffocation.

Histological findings consist of acute necrosis of the epidermis and muscle fibres with a mild or absent inflammatory reaction (Wolke 1975). The causative agent may be found on the surface of the lesions, under the scales and even in the intramuscular spaces.

Factors conditioning occurrence of the disease are high temperature, hardness and $\mathrm{pH}$ of water as well as a larger proportion of the organic matter and nutritional status of the fish. Higher incidence of the disease was found at water temperatures of about $18{ }^{\circ} \mathrm{C}$, experimentally confirmed in salmon by Ordal and Rucker (1944). Hard water containing larger amounts of organic matter is more favourable for survival of Fl. columnaris whereas soft and acid water with little organic matter destroys it (Wolke 1975). A direct effect of stock density on an outbreak of the disease found Fujihara and Olson (1962).

Importance of varying virulence of Flexibacter strains is obvious; it is noteworthy that Pacha and Ordal (1963) found differences even within one river basin. According to these authors strongly virulent $\mathrm{Fl}$. columnaris strains can cause the disease even at water temperatures below $13^{\circ} \mathrm{C}$.

\section{Casuistics}

In the course of feeding experiments in two hydrologically different localities, symptoms typical of columnarosis were observed in rainbow trout from May to August 1980.

Locality A: river water

Experimental fish (average length $180 \mathrm{~mm}$ and body mass $80 \mathrm{~g}$ ) were placed into 10 laminate containers $(8 \times 0.8 \times 0.8 \mathrm{~m})$ at a stock density of 300 per container. The hydrochemical parameters of the water flowing from submountainous river are given in Table 1. Its mean temperature was $7^{\circ} \mathrm{C}$.

After a lapse of six days the first symptoms of disease were observed. They consisted of oval lighter spots that tended to be grown over by moulds very rapidly. These lesions often spread from skin on fins which became fringed and had the bones exposed. In many diseased fish such lesions were found also on opercula. Pathoanatomical changes were accompanied by excitement and jumping of the fish above the water surface. Their food intake was not impaired.

With the onset of clinical symptoms also dying of the fish began. It culminated on day 4 (139 fish). Later the mortality slowly decreased and dying ceased on day 20 of the outbreak. The total loss was $390(13 \%)$ fish.

Parasitological examination revealed sporadic skin invasions of Apiosoma sp.

Table 1

Hydrochemical features of localities where columnarosis in rainbow trout (Salmo gairdneri $R$ ) was found

\begin{tabular}{|c|c|c|c|}
\hline Feature: & Unit: & $\begin{array}{l}\text { Locality A: } \\
(15.7 .1980)\end{array}$ & $\begin{array}{c}\text { Locality B: } \\
(19.6 .1980)\end{array}$ \\
\hline $\begin{array}{l}\text { Water temperature } \\
\text { pH } \\
\mathrm{O}_{2} \text { dissolved } \\
\text { Saturation with } \mathrm{O}_{2} \\
\text { Total alkality } \\
\text { Acidity } \\
\text { Total hardness } \\
\mathrm{Mn} \text { oxidability } \\
\mathrm{Ca}^{2+} \\
\mathrm{Mg}^{2+} \\
\mathrm{NH}_{4}^{+} \\
\mathrm{NO}_{3}^{+} \\
\mathrm{NO}_{2}^{-} \\
\mathrm{PO}_{4}^{3-} \\
\mathrm{Cl}^{-} \\
\mathrm{SO}_{4}^{2-} \\
\mathrm{HCO}_{3}^{-} \\
\mathrm{Fe} \text { total } \\
\text { Dissolved substances in sum }\end{array}$ & $\begin{array}{l}{ }^{\circ} \mathrm{C} \\
\mathrm{mg} \cdot 1^{-1} \\
\text { mval } \cdot 1^{-1} \\
\text { mval } 1^{-1} \\
{ }^{\circ} \mathbf{N}^{-1} \\
\mathrm{mg} \cdot 1^{-1} \\
\mathrm{mg} \cdot 1^{-1} \\
\mathrm{mg} \cdot 1^{-1} \\
\mathrm{mg} \cdot 1^{-1} \\
\mathrm{mg} \cdot 1^{-1} \\
\mathrm{mg} \cdot 1^{-1} \\
\mathrm{mg} \cdot 1^{-1} \\
\mathrm{mg} \cdot 1^{-1} \\
\mathrm{mg} \cdot 1^{-1} \\
\mathrm{mg} \cdot 1^{-1} \\
\mathrm{mg} \cdot 1^{-1} \\
\mathrm{mg} \cdot 1^{-1}\end{array}$ & $\begin{array}{l}9.8 \\
7.3 \\
10,1 \\
88 \\
0.6 \\
0.05 \\
4.8 \\
2.8 \\
22.0 \\
7.3 \\
0.01 \\
8.5 \\
0,030 \\
0,01 \\
4.6 \\
15.2 \\
36.6 \\
0.06 \\
81.0\end{array}$ & $\begin{array}{c}16.2 \\
6.8 \\
9.2 \\
96 \\
0.8 \\
0.02 \\
5.6 \\
1.7 \\
24.0 \\
97 \\
0.12 \\
14.8 \\
0.070 \\
0.01 \\
7,1 \\
24.9 \\
48.8 \\
0.06 \\
140.0\end{array}$ \\
\hline
\end{tabular}


Locality B: valley dam-lake

Experimental fish of the same origin as $A$ were placed into 20 net cages $(1.6 \times 1.1 \times 3 \mathrm{~m})$ at a density of 300 fish per cage. The cages were immersed $3 \mathrm{~m}$ below the water surface. The hydrochemical parameters are given in Table 1 . The water temperature in May and June averaged $16^{\circ} \mathrm{C}$, in July $17^{\circ} \mathrm{C}$ and in August $18^{\circ} \mathrm{C}$.

Five days after stocking, the same symptoms were observed as in the previous experiment. In addition, saddle-shaped lesions around the adipose fin were found. After erosion of the necrotic skin and crater-shaped ulceration of the musculature the bones became exposed and often the tail destroyed and lost (Fig. 1-4).

The death rate had a rather protracted course and dying culminated in August. The total loss amounted $1440(24 \%)$ fish. At fishing performed 120 days after the start of the experiment, $0.5 \%$ of the stock had to be condemned for low body mass, cachexia and stunted growth.

Parasitological examination revealed a single invasion of Ichthyophthirius multifiliis and Trichophrya piscium on gills and Gyrodactylus truttae on fins.

\section{Materials and Methods}

The aim of the present work was the bacteriological examination of the diseased fish, experimental infection of fish, and elucidation of the role of some aeromonads in the development of columnarosis.

Bacteriological procedures consisted of preparation and staining of tissue smears, inoculation of growth media and evaluation of microbial cultures. Special attention was given to Flexibacter strains. Growth and biochemical characteristics of these strains were followed in cultures incubated at $22^{\circ} \mathrm{C}$.

For bacterial isolation Anacker - Ordal's (1959) agar was employed. It served also for evaluation of the speed of gliding movement and for catalase and oxidase production (Kovács 1956). By addition of testing carbohydrates, bromthymol blue, and by pouring the medium on Petri dishes $(5 \mathrm{~cm}$ in diameter) a medium for fermentation experiments was prepared. Similarly, a solid medium for gelatin hydrolysis was prepared (Frazier 1926).

A fluid modification of the Anacker-Ordal's s medium was obtained by omitting of the agar. It was employed for description of the cultures and for the methylene blue reduction test. It also served as a basis for media used for $\mathrm{H}_{2} \mathrm{~S}$ and indole production, nitrate reduction and cellulose hydrolysis.

Urea decomposition was examined in a fluid modification of Christensen's medium (1946). Massively inoculated tubes were placed in a thermostat and observed for 5 days.

Dihydrolase activity in arginine and decarboxylation of lysine and ornithine were evaluated after 4 days of incubation of massively inoculated media after Möller (1955).

Sensitivity of Flexibacter strains to antibiotics was detected by paper discs (Lachema) placed on freshly inoculated Anacker-Ordal agar.

For isolation and examination of other bacteria common media and standard methods were employed (Pelczar et al. 1957; Cowan and Steel 1965).

After evaluation of all diagnostic features the individual strains were classified according to the VIII. Edition of Bergey's Manual (Buchanan and Gibbons 1974).

Biological experiments were carried out under laboratory conditions at water temperatures of $15^{\circ} \mathrm{C}$ and $20^{\circ} \mathrm{C}$. For this purpose one of the first isolates of both Fl. columnaris and $A$. punctata propagated in the fluid modification of the Anacker-Ordal agar (Fl. c.) or meat-peptone bouillon (A.p.). For biological experiments rainbow trout fry were used (average length $120 \mathrm{~mm}$ and body mass $14 \mathrm{~g}$ ). The fish had been adapted for 96 hours before being placed into glass aquariums (12 1) in groups of 5 . The fish or water were inoculated according to the scheme in Table 2 and observed for 16 days.

Permanently aerated water had the following chemical characteristics: $\mathrm{pH} 7.6$, hardness $11.3^{\circ} \mathrm{N}$, dissolved $\mathrm{O}_{2} 9.3 \mathrm{mg} .1^{-1}, \mathrm{O}_{2}$ saturation $100 \%$, oxidability by $\mathrm{KMnO}_{4} 1.8 \mathrm{mg} \cdot 1^{-1}, \mathrm{NH}_{4}^{+} 0.05$ $\mathrm{mg} \cdot 1^{-1}, \mathrm{NO}_{3}^{-} 15 \mathrm{mg} \cdot 1^{-1}$ and $\mathrm{NO}_{2}^{-} 0.040 \mathrm{mg} \cdot 1^{-1}$.

\section{Results}

From each of both localities 8 dead fish were examined. Gram-negative rod-shaped bacteria resembling the subtle cells of $F l$. columnaris were present in all tissue smears and they were successfully isolated on Anacker-Ordal's agar. 

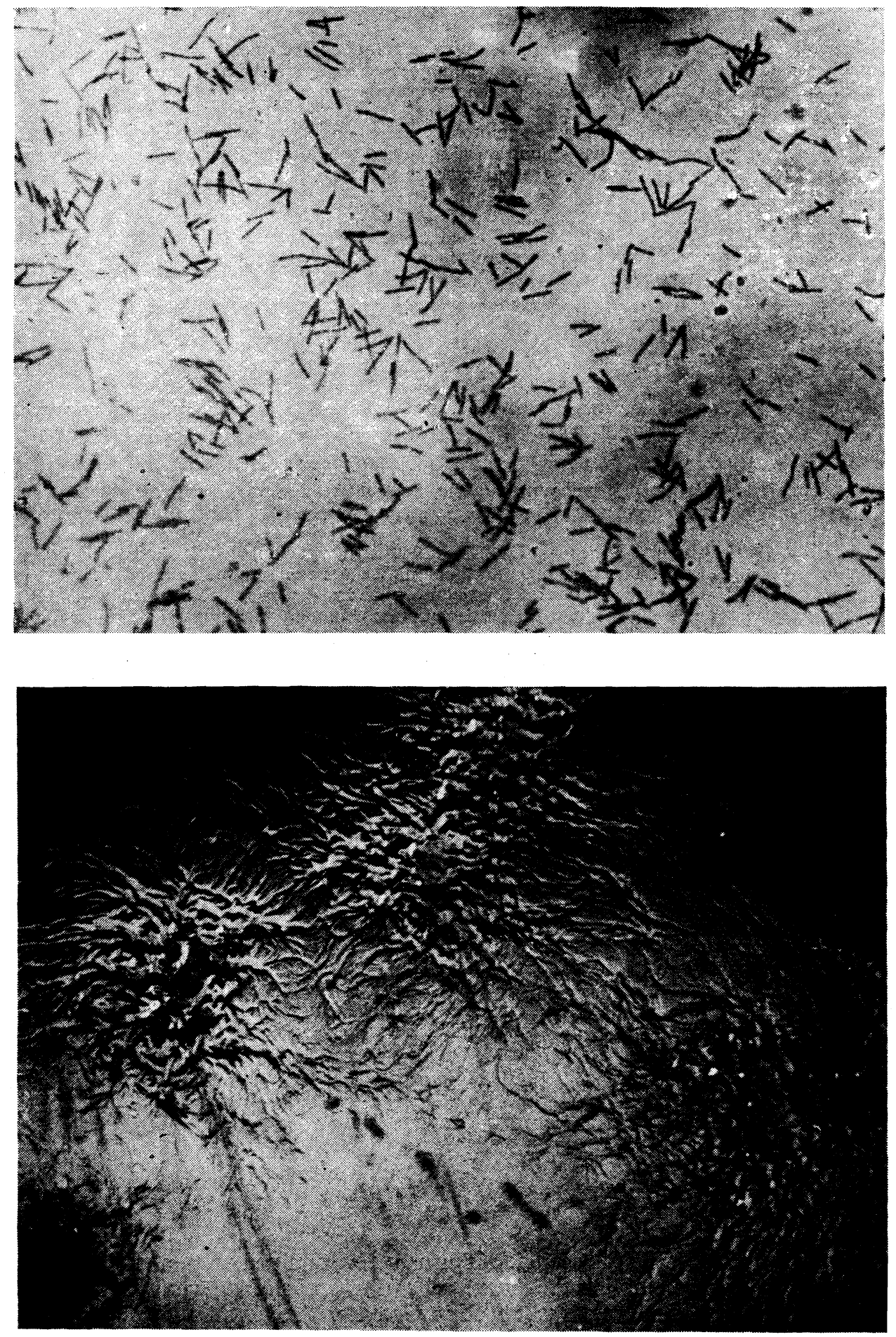
Fig. 5.

Stained preparation from $72-\mathrm{hr}$ culture of Flexibacter columnaris, strain $2 / 80$, grown in liquid modification of Anacker - Ordal medium. $\times 1000$.

Table 2

Inoculation scheme of biological experiments with F. columnaris and A. punctata

\begin{tabular}{|c|c|c|c|c|}
\hline $\begin{array}{l}\text { Aquarium } \\
\text { No. }\end{array}$ & $\begin{array}{l}\text { Number } \\
\text { of fishes }\end{array}$ & $\begin{array}{l}\text { Bacterial } \\
\text { species }\end{array}$ & $\begin{array}{l}\text { Inoculum } \\
\text { (No. of cells) }\end{array}$ & $\begin{array}{l}\text { Application } \\
\text { mode }\end{array}$ \\
\hline 1. & 5 & F. columnaris & $500 \cdot 10^{6} \cdot 1^{-1}$ & into the water \\
\hline 2 & 5 & $\begin{array}{l}F . \text { columnaris } \\
A . \text { punctata }\end{array}$ & $\begin{array}{l}500 \cdot 10^{6} \cdot 1^{-1} \\
500 \cdot 10^{6} \cdot 1^{-1}\end{array}$ & into the water \\
\hline 3 & 5 & A. punctata & $500 \cdot 10^{8} \cdot 1^{-1}$ & into the water \\
\hline 4 & 5 & 0 (control) & $\begin{array}{c}\text { sterile } \\
\text { nutr. media } \\
\left(1 \mathrm{ml} .1^{-1}\right)\end{array}$ & into the water \\
\hline 5 & 5 & F. columnaris & $60 \cdot 10^{8}$ & per os*) \\
\hline 6 & 5 & F. columnaris & $60 \cdot 10^{\circ}$ & intraperitoneally**) \\
\hline 7 & 5 & $\begin{array}{c}F . \text { columnaris } \\
A . \text { punctata }\end{array}$ & $\begin{array}{l}60 \cdot 10^{8} \\
60 \cdot 10^{8}\end{array}$ & per os \\
\hline 8 & 5 & $\begin{array}{c}F . \text { columnaris } \\
A . \text { punctata }\end{array}$ & $\begin{array}{l}60 \cdot 10^{6} \\
60 \cdot 10^{6}\end{array}$ & intraperitoneally \\
\hline 9 & 5 & A. punctata & $60 \cdot 10^{\circ}$ & per os \\
\hline 10 & 5 & A. punctata & $60.10^{8}$ & intraperitoneally \\
\hline
\end{tabular}

Comments:

$\left.{ }^{*}\right)$ = with a tube into the stomach.

**) $=$ on the left side, above the abdominal fin.

The unflagellated microbes were $0.2-0.4 \times 2-12 \mu \mathrm{m}$ in size. In older cultures, however, they were often present in the form of $12-20 \mu \mathrm{m}$ long filaments. In microscope, they were mostly situated single, rarely in pairs end to end or in short chains (Fig. 5). Their cultivation required aerobic conditions and a decreased $\mathrm{NaCl}$ and peptone content in the medium. The temperature limits are 13 and $30^{\circ} \mathrm{C}$ with an optimum between 20 and $25^{\circ} \mathrm{C}$.

They grew within 24-72 hours in Anacker-Ordal's agar to form yellowish colonies 2-4 $\mathrm{mm}$ in diameter with mat surface, medusa-shaped edges and later also a glossy, nipple-like centre. The peripheral outgrowths result form the gliding movements of cellular streams which divide or branch themselves before they slowly stop and attach to the medium surface (Fig. 6). In the fluid modification of this medium a silky turbidity was formed with an incomplete membrane on the surface and a slight sediment at the bottom of the test tube. After a mild shaking a moiré reminiscent of tobacco smoke was visible.

Biochemical tests were performed with 3 strains from each locality and the expe- . riments using carbohydrates were observed for 14 days. Positive results were ob-

Fig. 6.

Five-days' culture of Flexibacter columnaris, strain 2/80, on Anacker - Ordal medium. $\times 10$. 

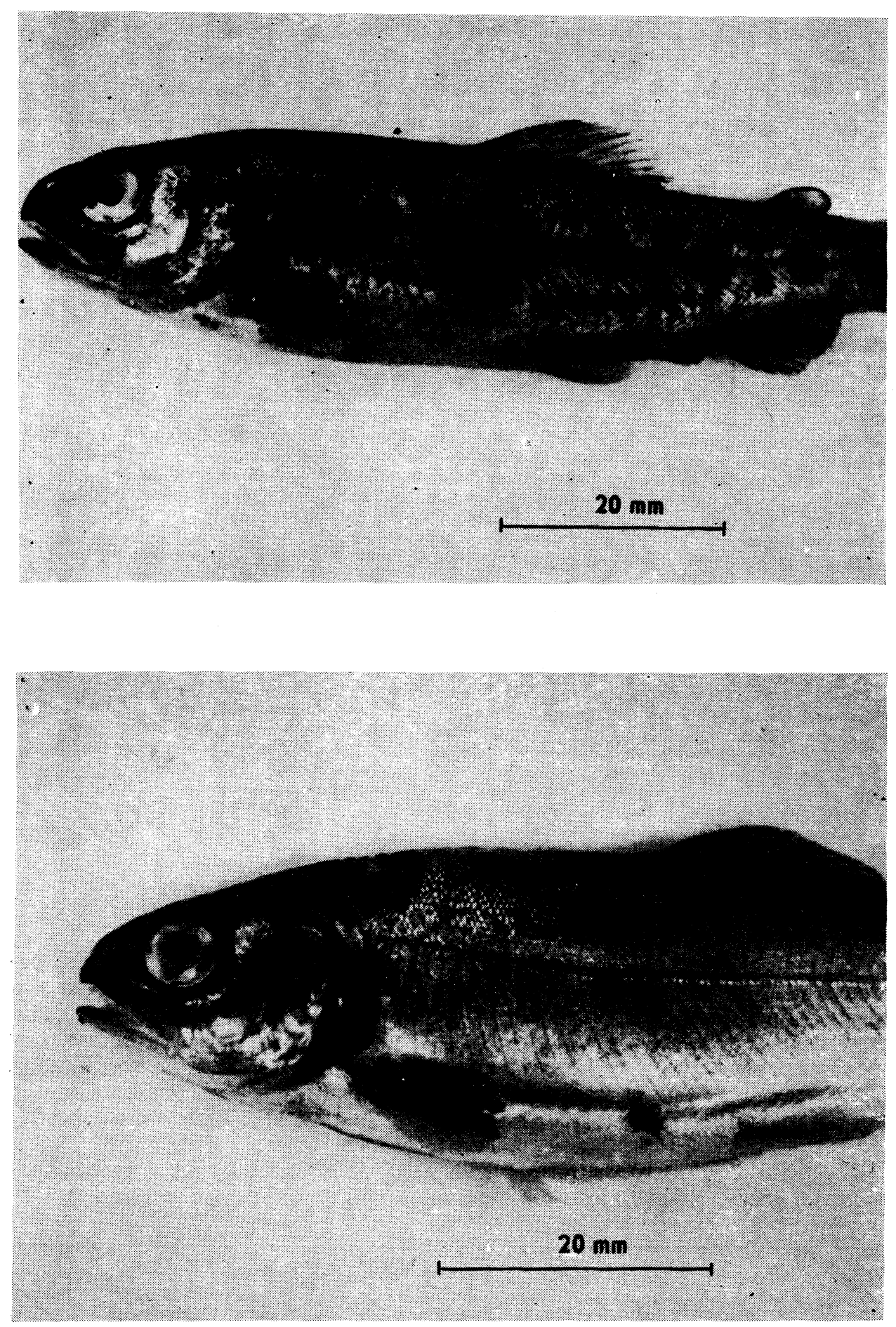

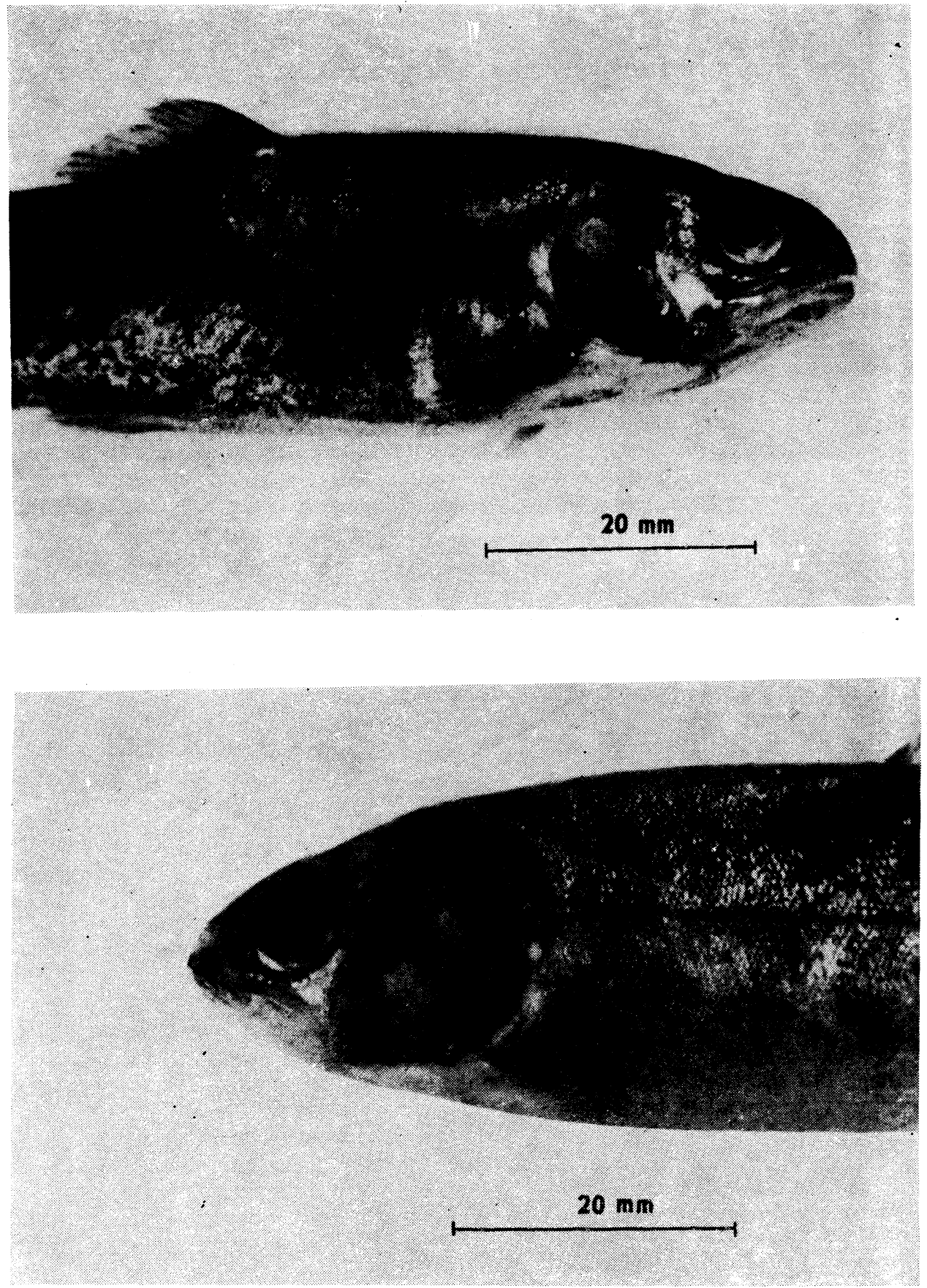

Fig. $7-10$.

Columnarosis in rainbow trout: necrotic lesions on skin, fins and gills. Experimental infection. 
tained with oxidative decomposition of glucose, gelatin hydrolysis, nitrate and methylene blue reduction, as well as production of $\mathrm{H}_{2} \mathrm{~S}$, catalase and oxidase. Tests for indole, hydrolysis of arginine and urea, decarboxylation of lysine and ornithine, decomposition of agar, cellulose, starch and other carbohydrates (lactose, maltose, saccharose, glycerol, mannitol, sorbitol, salicin) yielded negative results.

Among 31 antibiotics and chemotherapeuticals tested $F l$. columnaris strains were increasingly sensitive to tetracycline, streptomycin, cephalotin, carbenicillin, oleandomycin, erythromycin, spiramycin, chloramphenicol, sulfisoxazole, pristinamycin, novobiocin, fucidin, lincomycin and furadantin. Insufficient activity showed ampicillin, cephaloridine, gentamicin, neomycin and also oxytetracycline, and all Flexibacter strains were entirely resistant to bacitracin, kanamycin, colistin, methycillin nystatin (fungicidin), oxacillin paromomycin, penicillin, polymyxin $B$, sulfamethoxydine, sulfadimidine and vancomycin.

Besides Fl. columnaris strains, three times Aeromonas punctata, twice Pseudomonas aeruginosa, twice neisseriae, twice corynebacteriae and once Chromobacterium lividum were isolated and also water molds.

During the biological experiments at water temperature of $15^{\circ} \mathrm{C}$ only fish in aquariums No. 8 and 10 died as soon as $24-36$ hours after i. p. inoculation of $A$. punctata alone or combined with $\mathrm{Fl}$. columnaris. Considering the fact that the stock in other aquariums remained healthy during the entire observation period, $A$. punctata isolated also from the organs of the dead fish must be considered as the actual death cause.

In the second experiment at a water temperature of $20^{\circ} \mathrm{C}$ fish in aquariums No. $1,2,8$ and 10 died (in No. 1 within 36-72 hours, in No. 2 within $24-30$ hours, and in No. 8 and 10 within 24 hours). These results indicate the conditioning effect of higher water temperature and also the fact that Fl. columnatis infection occurred only by contact.

The necrotic lesions on the skin, fins and gills of the fish from aquariums No. 1 and 2 is shown in Fig. 7-10. Pathoanatomical changes were accompanied by intermittent excitation and depression, and swimming near the water surface which is indicative of increased oxygen demand of the diseased fish. In aquariums No. 8 and 10 where obviously an infection with $A$. punctata occurred, no signs of illness developed on the skin of the experimental fish.

\section{Discussion}

Observation of the natural course of the disease indicates that different water temperatures (average $7{ }^{\circ} \mathrm{C}$ and $17^{\circ} \mathrm{C}$ ) did not influence the development of columnarosis but the total loss at higher temperature was almost double. These facts are in good agreement with data of Pacha and Ordal (1963) and it can be explained by higher virulence of flexibacters, and by higher water temperature in the second case. This assumption is supported by the finding of saddle-shaped lesions (Fig. 1, 2, 4) found also by Ferguson (1977) in the rainbow trout under the same conditions. Among other factors, a considerable stress of manipulation at sorting, transport and stocking of the fish have probably made themselves felt.

Fl. columnaris strains isolated in our experiments agree fully with the species characteristics given by Leadbetter (1974) which was completed by nitrate and methylene blue reduction and by negative results of urea, arginine, lysine and ornithine tests. 
The biological experiments were performed as late as 4 months after isolation of $F l$. columnaris and $A$. punctata strains. This time lapse may provide an explanation of a considerable decrease in virulence expecially of $\mathrm{Fl}$. columnaris (Baxton and Fraser 1977) so that the organisms proved virulent only when potentiated by higher water temperatures. The most important results of these experiments was the finding of columnarosis infection exclusively by contact. Induced $\mathrm{Fl}$. columnaris infection itself is sufficient to cause death of affected fish. The species $A$. punctata which proved effective only at parenteral administration, can obviously cause only secondary infections after a microbial, parasitic or physical damage to the skin.

\section{Nález kolumnarózy u pstruha duhového (Salmo gairdneri R.) v ČSSR}

Autoři článku popsali první případy kolumnarózy ryb v ČSSR. Onemocnění se vyskytovalo od počátku května do konce srpna 1980, a to v souvislosti s krmnými pokusy $\mathrm{v}$ říční vodě a přehradní nádrži.

$V$ rríční vodě o teplotě $9,8^{\circ} \mathrm{C}$ byly na rưzných místech těla ryb zjištěny okrouhlé světlejši skrvny, a v přehradní nádrži o teplotě vody $16,2^{\circ} \mathrm{C}$ také ulcerace svaloviny $\mathrm{s}$ event. obnažením kostního podkladu. Spolu s teplotním rozdílem došlo i k poněkud odlišnému průběhu nákazy. $V$ prvním případě trvala 20 dní s celkovým úhynem $390(13 \%)$ ryb, zatímco ve druhém se hynutí vleklo po celou dobu krmného pokusu a úhrnné ztráty činily $1440(24 \%)$ ryb.

$\mathrm{Z}$ obou lokalit bylo vyšetřeno po osmi uhynulých rybách. Gramnegativní tyčinky druhu Flexibacter columnaris se nacházely ve všech tkáňových roztěrech, a úspěšnou byla $\mathrm{i}$ jejich izolace na Anacker-Ordalově agaru. Kromě toho se zjistily $3 \times$ ještě Aeromonas punctata, $2 \times P$ seudomonas aeruginosa, $2 \times$ neisserie, $2 \times$ korynebakterie a $1 \times$ Chromobacterium lividum, $\mathrm{z}$ ostatních agens také vodní plísně.

Za čtyři měsíce po těchto nálezech byly aranžovány biologické pokusy na plůdku pstruha duhového. Proběhly za použití jednoho kmene Flexibacter columnaris a jednoho kmene Aeromonas punctata, a to v laboratorních podmínkách prri teplotě vody 15 a $20^{\circ} \mathrm{C}$

$\mathrm{Z}$ inokulačního schematu (tab. 2) se podařilo reprodukovat kolumnarózní infekci kontaktním zůsobem (do vody) při teplotě $20^{\circ} \mathrm{C}$ a infekci druhem Aeromonas punctata intraperitoneálně při teplotě vody $15 \mathrm{i} 20^{\circ} \mathrm{C}$. Z těchto pokusů plyne zejména podmiňující účinek teplejší vody, rychlé oslabení virulence flexibakterových kmenů v laboratoři a sekundární povaha infekcí druhem Aeromonas punctata.

\section{Обнаружение колумнароза у радужной форели(Salmo gairdneri R.)в ЧСCP}

Авторами статьи описаны первые вспышки колумнароза рыб в ЧССР. Заболевание появлялось с начала мая под конец августа 1980 г., а именно в связи с кормовыми опытами в речной воде и плотинном водохранилище.

В речной воде при температуре $9,8^{\circ} Ц$ на разных местах тела рыб были определены более светлые пятна и в плотинном водохранилище при температуре воды $16,2^{\circ}$ Ц, также язвы в мускулатуре, евент. с обнажением скелета. Вместе с различием температуры заражение протекало несколько дифференџировано. В первом случае заражение продолжалось 20 дней с общим гибну- 
тием 390 (13\%) рыб, между тем, как в другом случае гибнутие рыб наблюдалось в течение всего кормового опыта и потери составляли итого 1440 (24\%) рыб.

В обеих местностях было исследовано по восьми погибшим рыбам. Грамнегативные палочки вида Flexibacter columnaris были найдены во всех тканевых мазках и удачной оказалась также их изоляция на агаре АнакераОрдала. Помимо того, определены 3 раза Aeromonas punctata, 2 раза Pseudomonas aeruginosa,2 раза нейссерии, 2 раза коринебактерии и 1 разChromobacterium lividum, из других агентов также водные плесни.

За четыре месяца после приведенных выше диагнозов были основаны биологические опыты над мальком радужной форели. Они протекали при использовании одного штамма Flexibacter columnaris и одного штамма Aeromonas punctata в лабораторных условиях при температуре воды 15 и $20^{\circ}$ Ц.

Из инокулящионной схемы (таб. 2) удалось воспроизводить колумнарозную инфекцию контактным способом (в воду) при температуре $20^{\circ} Ц$ и инфекцию видом Aeromonas punctata внтраперитонеально при температуре воды 15 и $20^{\circ}$ Ц. Из этих опытов вытекает обусловливающее действие более теплой воды, скорое ослабление вирулентности штаммов флексибактера в лаборатории и вторичный характер инфекции видом Aeromonas punctata.

\section{References}

ANACKER R. L., ORDAL E. J.: Studies on the myxobacterium Chondrococcus columnaris. I. Serological typing. J. Bact., 78, 1959: 25-32.

BUCHANAN R. E., GIBBONS N. E.: Bergey's Manual of Determinative Bacteriology. VIII. edit. Williams and Wilkins Co., Baltimore 1974. Pp. 1246.

BUXTON A., FRASER G.: Animal Microbiology. Vol. 1. Blackwell, Oxford - London Edinburgh - Melbourne 1977. Pp. 357.

CHRISTENSEN W. B.: Urea decomposition as a means of differentiating Proteus and paracolon cultures from each other and from Salmonella and Shigella types. J. Bact., 52, 1946: 461 -466.

COWAN S. T., STEEL K. J.: Manual for the Identification of Medical Bacteria. Cambridge Univ. Press, 1965. Pp. 217.

DAVIS H. S.: A new bacterial disease of fresh-water fishes. U. S. Fisheries Bull., 28, 1922: $261-$ 280.

FERGUSON H. W.: Columnaris disease in rainbow trout (Salmo gairdneri) in Northern Ireland. Vet. Rec., 101, 1977: 55-56.

FRAZIER W. C.: A method for the detection of changes in gelatin due to bacteria. J. Infect. Dis., 39, 1926: 302.

FUJIHARA M. P., OLSON P. A., quoted by BULLOCK G. L., McLAUGHLIN J. J. A.: Advances in knowledge concerning bacteria pathogenic to fishes (1954-1968). In SNIESZKO S. F.: Symposium on Diseases of Fishes and Shellfishes. Amer. Fish. Soc. Spec. Publ. No 5, Washington 1970. Pp. 526.

GARNJOBST L.: Cytophaga columnaris (Davis) in pure culture: A myxobacterium pathogenic to fish. J. Bact., 49, 1945: 113-128.

KOVÁCS N.: Identification of Pseudomonas pyocyanea by the oxidase reaction. Nature.(London), 178, 1956: 703.

LACHEMA n. e., Neratovice: Zkoušky citlivosti mikrobů diskovou metodou (cyclostyled instructions). 1970. Pp. 2.

LEADBETTER E. R.: Flexibacter. In BUCHANAN R. E., GIBBONS N. E.: Bergey's Manual of Determinative Bacteriology. VIII. edit. Williams and Wilkins Co., Baltimore 1974. Pp. 1246.

MÓLLER V.: Simplified tests for some amino acid decarboxylases and for the arginine dihydrolase system. Acta path. microbiol. Scand., 36, 1955: 158.

ORDAL E. J., RUCKER R. R.: Pathogenic myxobacteria. Proc. Soc. Exp. Biol. Med., 65, 1944: $15-18$ 
PACHA R. E., ORDAL E. J.: Epidemiology of columnaris disease in salmon. Bact. Proc., 63, 1963: 3.

PELCZAR M. J. et al.: Manual of Microbiological Methods. McGraw - Hill, New York-Toronto-London 1957. Pp. 315.

WAKABAYASHI H., KIRA K., EGUSA S.: Studies on columnaris disease of pond-cultured eels. II. The relation between gill disease and Chondrococcus columnaris. Bull. Jap. Soc. Sci. Fish., 36, 1970: 678.

WOLKE R. E.: Pathology of bacterial and fungal diseases affecting fish. In RIBELIN W. E., MIGAKI G.: Pathology of Fishes. University of Wisconsin Press, 1975. Pp. 1004. 